\title{
The Impact Of Customer Satisfaction On Business Growth For Kpj Penang Specialist Hospital, Malaysia
}

\author{
${ }^{1}$ AR. Abdul Aziz,${ }^{2}$ Rani,${ }^{3}$ N.Azizan \\ ${ }^{1,2}$ KPJ Penang Specialist Hospital, ${ }^{3}$ University Malaysia Pahang
}

\begin{abstract}
A retrospective study was done to collect data on the rating of services given by patients related to Nurses, Doctors ,House keeping, Facilities and Food for the whole year of 2012 and year 2013. Feedback forms were given to all patients admitted to KPJ Penang and collection was done upon patient's discharge. Data were later tabulated in term of graphic to compare the rating for year 2012 and 2013. Statistic for inpatients, outpatients, revenue and profit before tax were also collected for year 2012 and year 2013 to see the variance between both years. For year 2012 ,KPJ Penang had recorded 14,571 inpatients, 99,268 outpatients with total revenue of $R M 94,819,116.00$. With the increase rating given by customers in term of nursing services (7.5\%), doctors services (8.3\%), facilities (9.4\%), food (6.7\%) and housekeeping (5.8\%), the statistic and the hospital performances also increased for year 2013. Inpatient increased by $6.9 \%$ to 15,576, outpatients increased by $2.2 \%$ to 101,474 and total revenue increased by $9.5 \%$ to RM 103,154,577.00 in year 2013. Based on the data collected through customer feedback form in year 2012 and in year 2013 it was found that the rating for year 2013 increased from 5.8\% for housekeeping to 9.4\% for facilities. In line with this increase the statistic had also increased from $2.2 \%$ for outpatients to $6.9 \%$ for inpatients. In term of revenue there was an improvement of $9.5 \%$ for year 2013. With this data it was clearly shown that when rating of customer sevices provided increased, the revenue also increased.
\end{abstract}

Keywords: Retrospective study, feedback forms, rating of services, increased revenue

\section{Introduction}

According to (Faris, 2010), customer satisfaction is a measure on the number of customers or percentage of total customers that exceeds specific satisfaction goals in term of reported experience with a firm, its products or its services (rating).It was found that 71 percent of responden among 200 senior marketing managers quoted that a customer satisfaction metric is very useful in managing and monitoring their businesses. Customer satisfaction is also a measure of how products and services supplied by a company meet or surpass customer expection .

Companies growth is measured through customer satisfaction because it is a key differentiator and key element of business strategy (Gitman, 2005). It is also part of balance scorecard and is seen as a key performance indicator within business. Satisfied customers will likely to make a repeat purchases and often refers others.Therefore it serves as an indicator for increase of sales and monitoring should be done continuously

Customers will be satisfied with high quality products and this will increase repeat purchases which will lead to higher profits. Matzlet et. al (2004) reported that many companies use some form of customer satisfaction programme in developing, monitoring and evaluating their products and services, formulate strategies to enhance satisfaction, and compensate employees based on satisfaction ratings. When an organization creates a benefit for customers it will effect customer loyalty and they will maintain and increasingly repeat business with the organization (Anderson, \& Jacobsen, 2000). It is in fact a deeply held commitment of customers to prefer products or services of a particular organization in future despite situational constraints or marketing influences to cause the switching behavior. True customer loyalty is created when customers become advocate of an organization without any incentive (Oliver, 1999).

In order to motivate customers, organization must be able to build and maintain long lasting relationships with them by satisfying their needs and demands so that they will continue their business with the organization on long term basis. By doing this the organization can retain their customers.(La Barbera, \& Mazursky, 1983).In a competitive markets the suppliers must go beyond mere basic satisfaction and to look for ways of establishing ties of loyalty that will help ward off competitor attack (Clarke, 2001). In selling process , customer satisfaction is the key aim and it is estimated that it costs five times as much to attract new customers as to retain an existing one.The management guru, Peter Drucker states, "The purpose of a business is to create and retain customers." So where do you start? "If I or my company choose to spend money with you, you have to earn it." 
The service-profit chain establishes relationships between profitability, customer loyalty, and employee satisfaction, loyalty, and productivity. The links in the chain (which should be regarded as propositions) are as follows: Profit and growth are stimulated primarily by customer loyalty. Loyalty is a direct result of customer satisfaction. Satisfaction is largely influenced by the value of services provided to customers. Value is created by satisfied, loyal, and productive employees. Employee satisfaction, in turn, results primarily from high-quality support services and policies that enable employees to deliver results to customers.

In the era of customer-oriented business strategy, the 80/20 rule was a very popular credo of business professionals.For most companies, $80 \%$ of their profitable revenue comes from just $20 \%$ of their clients.Therefor beside finding the right customers, it is also important for an organization to retain the continued business of these loyal clients.

Short and long-term value in customer loyalty and market place alliances can be created through the understanding and fortering key relationships. Surveying customers, then, makes very sound and fundamental business sense.Surveying is critical to the health and the vitality of these relationships which will effect the business itself.Therefore it is hard to ignore the profound business effect of those $80 / 20$ relationships.It is also critical for the present and future success of most businesses to discover, develop and nurturing customers .Therefore by identifying key customers, it is only one step of creating this profitable relationship; to maximize profits, companies must continuously collect ongoing data about these customers or groups. Through this effort, a business can truly create one-to-one relationships with its clients and create opportunities for continued business with upsells, renewals, cross sells, and referrals.

When it comes to sustainable profit growth in business, customer loyalty is no doubt a major contributor. A business firm cannot afford to lose it customers especially in the current economic environment which is quite volatile. This principle is applicable to all small and big business firms, irrespective of which section of the society they cater to, or how long they have been in business. A customer will seldom come back to you when he had turned his back to your business because he had so many options available for him out there. In the present situation bringing new customers is much easier than to retain the existing customers. Therefore measuring customers staisfaction will facilitate companies to measure their services..

\section{Objectives}

1. To compare the rating of customer satisfaction for year 2012 and year 2013

2. Monitor various statistics for outpatients and inpatient services for year 2012 and year 2013

3. To see whether the increase in the rating of customer satisfaction is significant in term of the increase for statistics and revenue generated for both year 2012 and 2013

\section{Methodology}

A retrospective study was done to collect data on the rating of services given by patients related to Nurses, Doctors ,House keeping, Facilities and Food for the whole year of 2012 and year 2013. Feedback forms were given to all patients admitted to KPJ Penang and collection was done upon patient's discharge. Data were later tabulated in term of graphic to compare the rating for year 2012 and 2013. Statistic for inpatients and outpatients were also collected for year 2012 and year 2013 to compare the different between both years . Data for Total revenue and Profit before tax were also collected to see the increase between year 2012 and year 2013.

1.Rating For Nurses

\section{Result}

NURSING RATING FOR YEAR 2012(JAN-DEC) \& 2013 ( JAN-DEC)

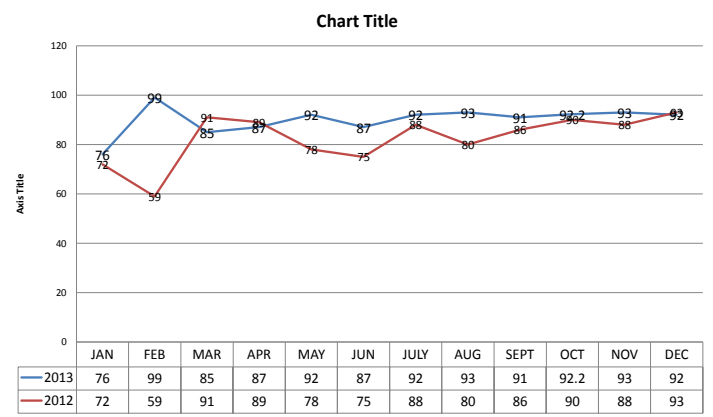

Average rating for 2012 was $82.4 \%$; average rating for 2013 was $89.9 \%$ Variance is $7.5 \%$ 
1. Rating For Doctors

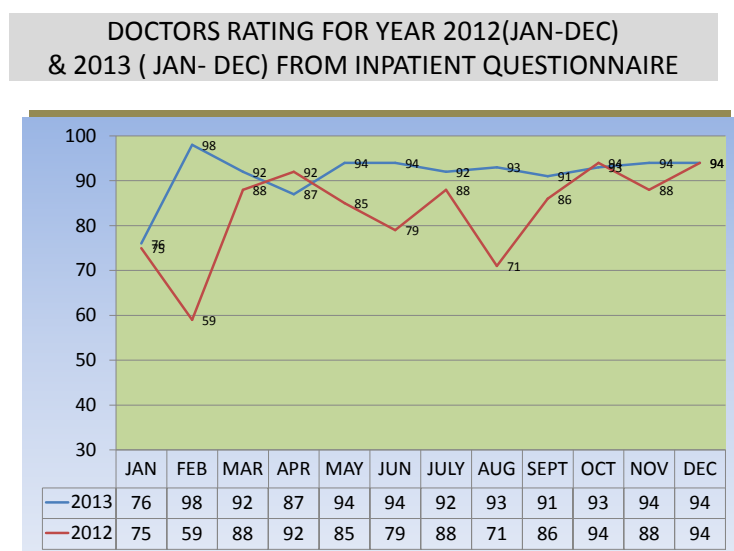

Average rating for 2012 was $83.2 \%$; average rating for 2013 was $91.5 \%$.

Variance is $8.3 \%$

2. Rating For Facilities

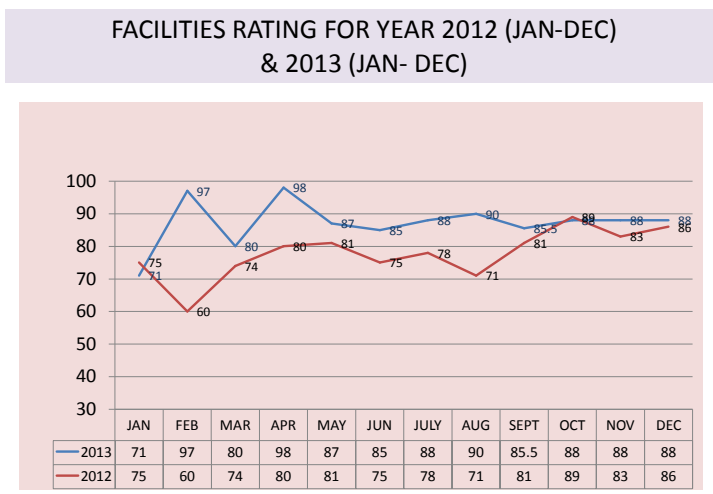

Average rating for 2012 was $77.7 \%$; average rating for 2013 was $87.1 \%$ Variance is $9.4 \%$

3. Rating For Food Provided

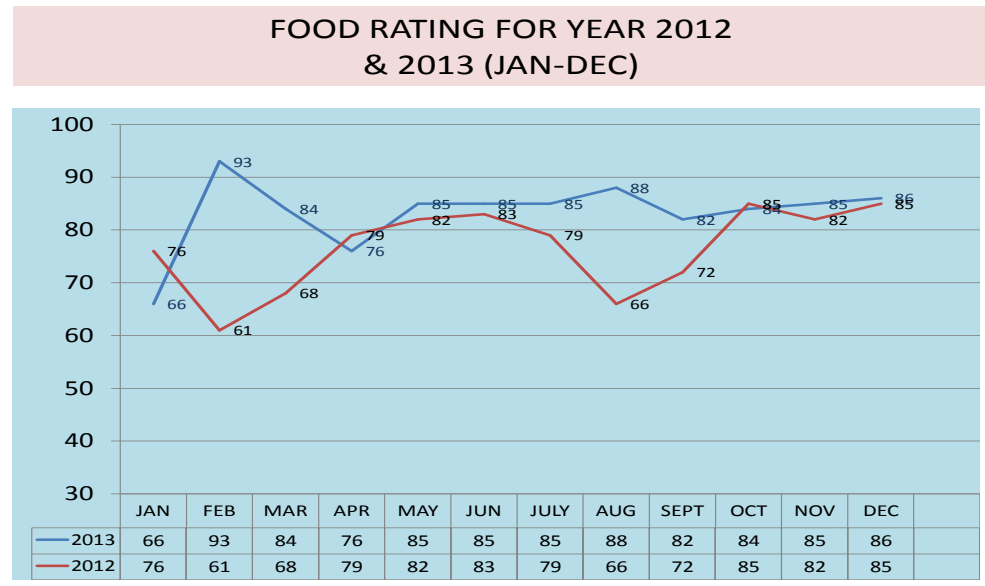

Average rating for 2012 was $76.5 \%$; average rating for 2013 was $83.2 \%$ Variance is $6.7 \%$ 
5.Rating For Housekeeping

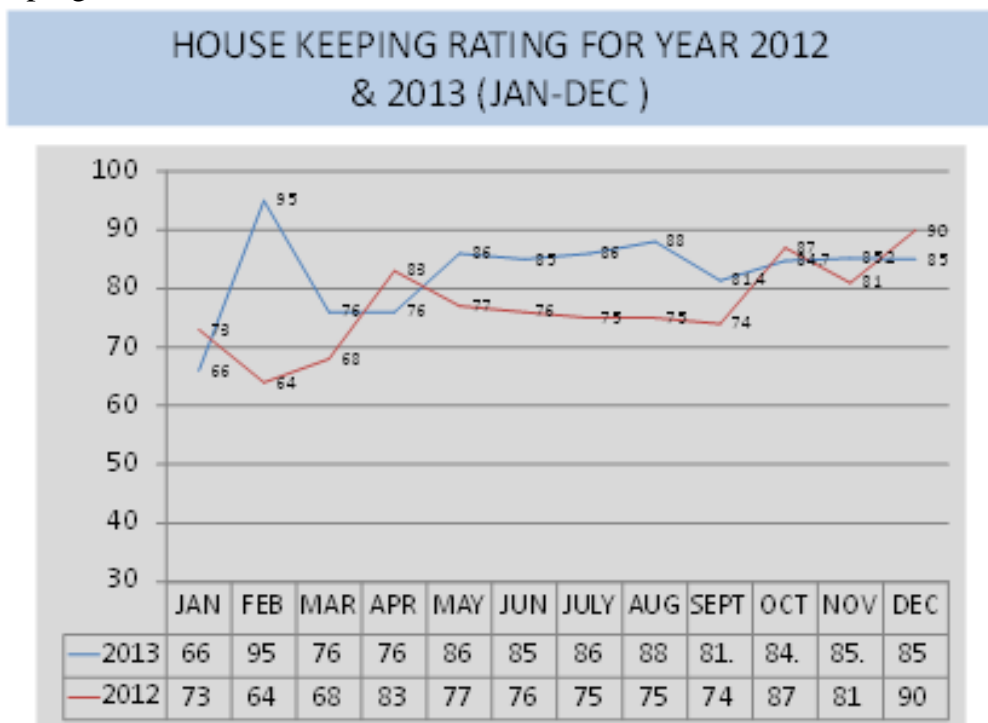

Average rating for 2012 was $76.9 \%$; average rating for 2013 was $82.7 \%$ Variance is $5.8 \%$

4. Statistic For Outpatients/Inpatients / Revenue

\begin{tabular}{|l|l|l|l|}
\hline STATISTIC & 2012 & 2013 & VARIANCE \\
\hline Total Inpatients & 14,571 & 15,576 & $6.9 \%$ \\
\hline Total Outpatients & 99,268 & 101,474 & $2.2 \%$ \\
\hline Total Revenue & RM 94,819,116 & RM 103,154,577 & $9.5 \%$ \\
\hline
\end{tabular}

\section{Discussion}

For KPJ Penang Specialist Hospital, the Management had set the target of $80 \%$ rating as excellant for all types of services. For nursing services, in year 2012 the rating given by our customers was $82.4 \%$ and the rating for 2013 was $89.9 \%$ which was better by $7.5 \%$ compared to the previous year. In term of service provided by our doctors the rating for 2013 was $91.5 \%$ which was better compared to 2012 by $8.3 \%$ where year 2012 recorded a rating of $83.2 \%$.In Malaysia patients are still doctors' oriented, meaning to say they will come for treatment in any private hospitals because of the doctors and some patients will follow where ever their doctors go. The criteria is because they are happy in their choice when they received the medical treatment that may save their life(ConsumerReport.org). Therefore the services provided by doctors are very crucial in private hospitals. Anthony Downws et.al conducted a study in 1991 and they found that patients identified the hospital doctor as being more knowledgeable and prefer to follow-up care when compared to their general practitioner and they are prepared to be inconvenienced to achieve hospital follow-up.In this study it involved 372 patients attending 17 different clinics over a two day period at East Birmingham Hospital and study was conducted through the distribution of a questionnaire.In another study conducted by Schmittdiel et al. (1997) through a survey of 10,205 HMO patients, it was that the main reasosn for having high overall satisfaction was because patients can choose their physician. Excellent rating was given by 16 per cent to 20 percent more patients who can choose their personal physician $(n=4,748)$.

Rating given by patients for the facilities was $77.7 \%$ in year 2012 and this rating increased to $87.1 \%$ for year 2013. Therefore there was an improvement of $9.4 \%$. In a review of more than 600 articles, researchers found that there was a link between the physical environment (i.e., single-bed or multiple-bed patient rooms) and patient (e.g., fewer adverse events and better health care quality) and staff outcomes (e.g.,reduced stress and fatigue and increased effectiveness in delivering care). Therefore improving facilities will effect patient's choice and will increase the number of patients seeking treatment in a particular hospital. In another study, it was found that environmental satisfaction was a significant predictor of overall satisfaction, ranking only below perceived quality of nursing and clinical care.

(Harris, P. B., McBride, Ross, \& Curtis, 2002).

Based on the feedback form, patients had given the rating of $76.5 \%$ for food in year 2012 and $83.2 \%$ in year 2013. Therefore there was an increase of $83.2 \%$ for year 2013 compared to 2012. Research suggests that hospital food is an important part of the patient experience, and contributes to patient satisfaction, or dissatisfaction with their care. Anne Marie Males, VP of Patient Experience at Scarborough General Hospitals says "Food service is not considered a key department of most hospitals. It's a service that it has to be there. A lot of people don't give it much thought, but when you talk to patients, its amazing how important food is to 
them. Food served in hospitals has been found to be one of the major influences on overall patient satisfaction during a patient's hospital stay. In a study of patients, McKinnon (2007) found that patients believe they do not have control over anything during their hospitalization. Food choice is one important area where patients may seek to have greater control. Food service quality can also influence patients' satisfaction with their overall hospital experience (McLymont, Sharon, \& Stell, 2003; Williams, Virtue, \& Adkins, 1998). Therefore the Management of KPJ is very concern about the quality of food provided to all inpatients in this hospital.

The environment of the hospital can also play a critical role in hospital customer satisfaction. Above all, patients want to know that the facility is clean, sterile and safe, and that proper disease control procedures are followed consistently. They also, however, want patient rooms and common areas such as waiting rooms to be warm, comfortable and inviting. . In KPJ Penang, housekeeping services will be taking care of the cleanliness of the hospital including patient's room . Based on the customer survey form collected at KPJ Penang it was found that rating for year 2012 was $76.9 \%$ and the rating increased by $5.8 \%$ to $82.7 \%$ in year 2013 .

Within the NHS, Hotel Services are usually classified as services around cleaning, catering, linen and laundry, and portering.It was suggested by Angelopoulou et al (1998) that patient may use hostel services aspects to judge the quality of hospital care when they are unable to use the clinical outcomes. In another study Liyanage et. al 2005, it was found that the hotel aspects in the hospital will last long lasting which is part of the integrated care package.

For year 2012 ,KPJ Penang had recorded 14,571 inpatients , 99,268 outpatients with total revenue of RM 94,819,116 .00. With the increase rating given by customers in term of nursing services (7.5\%), doctors services $(8.3 \%)$, facilities $(9.4 \%)$, food $(6.7 \%)$ and housekeeping $(5.8 \%)$, the statistic and the hospital performances also increased for year 2013. Inpatient increased by $6.9 \%$ to 15,576 , outpatients increased by $2.2 \%$ to 101,474 and total revenue increased by $9.5 \%$ to RM $103,154,577.00$ in year 2013 .

\section{Conclusion}

Based on the data collected through customer feedback form in year 2012 and in year 2013 it was found that the rating for year 2013 increased from 5.8\% for housekeeping to $9.4 \%$ for facilities . In line with this increase the statistic had also increased from $2.2 \%$ for outpatients to $6.9 \%$ for inpatients. In term of revenue there was an improvement of $9.5 \%$ for year 2013. With this data it was clearly shown that when rating of customer sevices provided increased the revenue also increased.

\section{Literatures}

[1]. Anderson EW, Sullivan M (1993). The antecedents and consequences of customer satisfaction for firms. Mark. Sci., 12(2):125-143

[2]. Angelopoulou, P. Kangis, P and Babis, G (1998), Private and Public Medicine, A Comparison of Quality Perceptions,International Journal of Health Care Quality Assurance,

[3]. Vol. 11 No. 1 pp.14

[4]. Buzzle. Why is customer satisfaction important (online). http://www.buzzle.com/articles/why-is-customer-satisfactionimportant.html

[5]. Clarke, K. (2001). What Price on Loyalty When a Brand Switch is Just a Click Away?,. Qualitative Market Research: An International Journal, 4 (3), 160-168.

[6]. Cvent ,Online Solutions for Events \& Surveys. Why customer satisfaction matters (online).http://www.cvent.com/en/web-surveysoftware/customer-satisfaction-matters.shtml

[7]. Farris, Paul W.; Neil T. Bendle; Phillip E. Pfeifer; David J. Reibstein (2010). Marketing Metrics: The Definitive Guide to Measuring Marketing Performance. Upper Saddle River, New Jersey: Pearson Education, Inc. ISBN 0-13-705829-2.

[8]. Gitman, Lawrence J.; Carl D. McDaniel (2005). The Future of Business: The Essentials. Mason, Ohio: South-Western. ISBN 0324-32028-0.

[9]. Harris, P. B., McBride, G., Ross, C., \& Curtis, L. (2002). A place to heal: Environmental sourcesof satisfaction among hospital patients.Journal of Applied Social Psychology, 32(6),1276-1299

[10]. Heskett, J.L. et al. 2008. Putting the services profit chain to work. The Magazine. Harvard Business Review LaBarbara, P.A. and Mazursky, D. 1983. A longitunal assessment of consumer satisfaction/dissatisfaction, the dynamic aspect of the cognitive process, Journal of Marketing Research. Vol.20.pp: 393-404

[11]. Liyanage, C and Egbu, C (2005), Controlling Healthcare Associated Infections (HAI) and the Role of Facilities Management in Achieving "Quality" in Healthcare: A Three dimensional View,Facilities, Vol. 23 No. 5/6 pp. 194

[12]. McLymont, V., Sharon, C., \& Stell, F. (2003). Improving patient meal satisfaction with

[13]. room service meal delivery.Journal of nursing care quality, 18(1), 27-37.

[14]. Ulrich R, Quan X, Zimring C, et al. The role of the physical environment in the hospital of the 21st century: a once-in-a-lifetime opportunity. Report to The Center for Health Design, for the designing for the 21 st century hospital project, 2004. Accessed at www.healthdesign.org/resear ch/reports/physical_environ.php.

[15]. Wisegeek. Factors affect hospital customer satisfaction. (online).http://www.wisegeek.com/what-factors-affect-hospital-customersatisfaction.htm 